\title{
Pemberdayaan Masyarakat melalui Penyuluhan Pembuatan Pakan Fermentasi dan Pupuk Organik di Desa Trebungan, Kabupaten Bondowoso
}

\author{
Mila Riskiatul Rohma ${ }^{1}$, Sumbahri $^{2 *}$ \\ Universitas Jember, Jalan Kalimantan No 37 Kampus Tegalboto, Kec. Sumbersari - Kab. Jember - \\ Prov. Jawa Timur \\ Email:sumbahri@gmail.com²*
}

(Diajukan: 10 November 2021, Direvisi: 26 Desember 2021, Diterima: 01 Januari 2022)

\begin{abstract}
ABSTRAK
Desa Trebungan berlokasi di Kecamatan Taman Krocok Kabupaten Bondowoso, Kondisi geografis berada di ketinggian 247 meter DPL. Mayoritas masyarakat di Desa Trebungan memiliki mata pencaharian sebagai petani dan peternak. Permasalahan yang dihadapi masyarakat Desa Trebungan adalah kurangnya pemanfaatan limbah pertanian seperti jerami padi dan jagung, serta limbah kotoran ternak yang dibuang dan dibakar pada ladang atau tegalan. Tujuan dari program Meningkatkan pengetahuan dan keterampilan pada masyarakat tentang teknologi dan inovasi pengolahan limbah pertanian menjadi pakan ternak dan pengolahan limbah menjadi pupuk sehingga terbentuk sistem intergrasi tanaman pangan dan ternak. Kegiatan dilaksanakan di Desa Trebungan Kecamatan Tamankrocok Kabupaten Bondowoso pada bulan Agustus- Oktober 2021. Kegiatan ini di ikuti oleh mahasiswa anggota kelompok Tim PHP2D Himaproster, Fakultas Pertanian, Universitas Jember dan Mitra yaitu kelompok Tani-Ternak Subur Makmur, pengusaha peternakan lokal dan masyarakat. Metode Pelaksanaan meliputi sosialisasi pengenalan dan pemberian materi, demostrasi penyuluhan praktek pembuatan pakan fermentasi dan pupuk organik, evaluasi dan monitoring. Hasil kegiatan diketahui bahwa Potensi pakan ternak ruminansia di Desa Trebungan dari limbah pertanian adalah sekitar 1.991 UT dari komiditas padi dan jagung masing-masing seluas 229 Ha dan $204 \mathrm{Ha}$. Potensi Hasil kotoran ternak segar sebesar 19,14 - 25,520 ton KTS sapi/hari dan 0,850 ton KTS kambing dan domba/hari sehingga dalam satu bulan dapat memproduksi 765,60 ton kotoran sapi dan 25,50 ton kotoran kambing dan domba. Kegiatan program ini memiliki dampak postif bagi peningkatan pengetahuan peternak terkait teknologi pengolahan pakan dan pupuk organik melalui pemanfaatan limbah pertanian dan peternakan.
\end{abstract}

Kata kunci: Limbah Pertanian, Fermentasi, pupuk Organik

\begin{abstract}
Trebungan Village is located in Taman Krocok District, Bondowoso Regency, Geographical conditions are at an altitude of 247 meters above sea level. The majority of people in Trebungan Village have a livelihood as farmers. The problem faced by the people of Trebungan Village is the lack of utilization of agricultural waste such as rice straw and corn, as well as livestock manure that is disposed of and burned in fields. The purpose of the program is to increase knowledge and skills in the community about technology and innovation in processing agricultural waste into animal feed and processing waste into fertilizer so that an integrated system of food crops and livestock is formed. The activity was carried out in Trebungan Village, Tamankrocok District, Bondowoso Regency in August-October 2021. This activity was attended by student members of the Himaproster PHP2D Team, faculty of Agriculture, University of Jember and Partners, namely the Subur Makmur Farmers-Livestock group, local livestock entrepreneurs and the community. Implementation methods include socialization of introduction and provision of material, demonstration of counseling on the practice of making fermented feed and organic fertilizer, evaluation and monitoring. The results of the activity show that the potential for ruminant feed in Trebungan Village from agricultural waste is around 1,991 UT from rice and corn commodities, each covering an area of $229 \mathrm{Ha}$ and $204 \mathrm{Ha}$. The
\end{abstract}


potential yield of fresh manure is 19.14 - 25.520 tons of KTS cattle/day and 0.850 tons of KTS goats and sheep/day. In one month it can produce 765.60 tons of cow dung and 25.50 tons of goat and sheep dung. This program activity has a positive impact on increasing knowledge of farmers regarding feed processing technology and organic fertilizers through the use of agricultural and livestock waste.

\section{Keywords: Agricultural Waste, Fermentation, Organic Fertilizer}

\section{PENDAHULUAN}

Desa Trebungan berlokasi di Kecamatan Taman Krocok Kabupaten Bondowoso, dengan kondisi geografis berada diketinggian 247 meter diatas permukaan laut. Desa Trebungan Kecamatan Taman Krocok Kabupaten Bondowoso berada pada titik koordinat Bujur 113,86062 Bujur Timur koordinat lintang 07,89357 Lintang selatan. Mayoritas masyarakat di Desa Trebungan memiliki mata pencaharian sebagai petani dan peternak. Profesi peternak merupakan pekerjaan sampingan penduduk di Desa Trebungan. Rata-rata ternak yang dibudidayakan oleh penduduk sekitar adalah ternak ruminansia dan ruminansia kecil besar yaitu sapi potong, kambing dan domba. Jumlah populasi ternak sebanyak 638 ekor dan ternak ruminansia kecil yaitu kambing dan domba dengan jumlah populasi 162 ekor dan 263 ekor (Data Desa Trebungan, 2021).

Desa Trebungan merupakan salah satu desa yang terletak kurang lebih 8,3 Km dari pusat Kota Kabupaten Bondowoso (Gambar I). Populasi penduduk Desa Trebungan mencapai 1.294 jiwa, dengan mayoritas mata pencaharian dari penduduk adalah petani dan peternak yang jumlahnya mencapai 687 jiwa. Besarnya penyerapan tenaga kerja dari bidang pertanian dan peternakan menjadi sasaran yang tepat untuk mengembangkan potensi dari Desa Trebungan.

Kondisi SDM di Desa Trebungan tergolong masih rendah, dibuktikan dengan tingkat pendidikan dari masyarakat yang masih rendah, bahkan 25\% dari penduduknya tidak tamat SD. Selain rendahnya tingkat SDM, petani dan peternak juga mengalami beberapa permasalahan yang meliputi cara mengatasi permasalahan kelangkaan pakan yang terjadi saat musim kemarau, kelangkaan pupuk dan harga yang terus melonjak tinggi, serta bagaimana cara untuk mengimplementasikan sistem integrasi tanaman pangan dan ternak. Rendahnya Sumber Daya Manusia (SDM) Peternak di Desa Trebungan menjadi faktor dari keterbatasan pemanfaatan limbah pertanian sebagai pakan ternak. Limbah pertanian oleh masyarakat sekitar biasanya diberikan secara langsung pada ternak tanpa ada pengelolahan dan jika tidak termanfaatkan lagi maka akan dibakar untuk mempermudah pembersihan lahan pertanian. Permasalahan lain yang dihadapi masyarakat Desa Trebungan adalah limbah kotoran ternak yang dibuang dan dibakar pada ladang atau tegalan. Pembakaran 
limbah pertanian dan limbah kotoran ternak merupakan tindakan yang merugikan karena selain dapat mencemari lingkungan juga membahayakan kesehatan makhluk hidup. Oleh karena itu, dibutuhkan suatu program pemberdayaan sebagai upaya meningkatkan ketrampilan peternak dalam teknologi pengolahan limbah untuk mengoptimalkan sektor pertanian- peternakan.

Program sosialisasi inovasi pengolahan limbah pertanian dan peternakan ini dipelopori dan didampingi oleh tim Program Holistik Pengabdian dan Pemberdayaan Desa (PHP2D) Himpunan Mahasiswa Peternakan (Himaproster), Universitas Jember bersama permerintah dan masyarakat petani-peternak di Desa Trebungan. Kegiatan ini merupakan bentuk implementasi dari pengabdian terhadap masyarakat dalam rangka mewujudkan peran aktif mahasiswa sebagai agen perubahan. Adapun tujuan dari kegiatan ini antara lain:

a. Meningkatkan pengetahuan dan keterampilan pada masyarakat tentang teknologi dan inovasi pengolahan limbah pertanian menjadi pakan ternak yang berkualitas dan memperpanjang masa simpan guna mengatasi kelangkaan pakan dimusim kemarau.

b. Meningkatkan pengetahuan dan keterampilan kepada masyarakat tentang teknologi dan inovasi pengolahan limbah budidaya ternak menjadi pupuk organik yang diperkaya dengan mikroorganisme potensial.

c. Meningkatkan pendampingan dan penyuluhan kepada masyarakat tentang sistem pertanian dan peternakan terintegrasi guna meningkat kemadirian, kesejahteraan masyarakat, dan mewujudkan pembangunan berkelanjutan.

\section{METODE}

Kegiatan program pemberdayaan dan pengabdian desa oleh Himpunan Mahasiswa Program Studi Peternakan (HIMAPROSTER ), Fakultas Pertanian, Universitas Jember dilaksanakan selama kurang lebih 2 bulan, dimulai pada bulan September-Oktober 2021 di Desa Trebungan, Kecamatan Taman Krocok, Kabupaten Bondowoso. Kegiatan berupa penyuluhan, simulasi, demonstrasi atau praktek dan pendampingan pada kelompok taniternak. Kegiatan ini dipelopori oleh Tim PHP2D sebanyak 15 orang yang merupakan mahasiswa Program Studi Peternakan, Fakultas Pertanian Universitas Jember. Mahasiswa yang terlibat dalam kegiatan ini berjumlah sebanyak 15 orang. Mitra atau target dari pelaksaanaan ini adalah Kelompok tani-ternak, pengusaha peternak lokal dan masyarakat sekitar. 


\section{Tahap pelaksanaan kegiatan}

Pelaksanaan kegiatan PHP2D diawali dengan pembekalan yang dilakukan oleh Dosen pembimbing untuk pengarahan teknis kegiatan dilapangan, kemudian dilanjutkan dengan metode pendekatan serta koordinasi pada perangkat desa dengan anggota kelompok taniternak.

Pengenalan dilakukan pada awal pertemuan saat survei dan kunjungan lapang untuk memperlancar kegiatan kedepan. Pembukaan dan penyampaian materi dilakukan pada saat sosialisasi melalui arahan Dosen pembimbing dan perangkat desa, serta materi yang disampaikan mengenai potensi dan manfaat penggunaan limbah pertanian sebagai pakan ternak, kemudian dilanjutkan dengan pembuatan pupuk organik. Pengenalan yaitu kegiatan PHP2D berupa sosialisasi yang dilaksanakan pada tanggal 22 Agustus 2021 dan 10 September 2021 bertempat di Balai Desa Trebungan, Kecamatan Taman Krocok, Kabupaten Bondowoso. Rundown kegiatan yaitu mengisi daftar hadir, pembukaan, Sosialisasi, Diskusi, dan pengisian kuesioner.

Demomstrasi praktik dilapang untuk pembuatan pakan fermentasi dan pupuk organik dilakukan pada tanggal 4- 10 Agustus 2021 bertempat di halaman posko tim PHP2D. Pada kegiatan ini, Tim PHP2D memberikan teori sekaligus praktik terkait tata cara pembuatan pakan fermentasi dan pupuk organik. Pada tahap praktik peserta dipandu oleh tim PHP2D bersama-sama membuat pakan fermetasi dan pupuk organik Agenda dari kegiatan praktikum diantaranya adalah: Pembukan, praktik pembuatan pakan fermentasi dan pupuk organik, dokumentasi dan Penutup.

\section{Pembuatan pakan fermentasi, dan pupuk organik:}

\section{Pakan fermentasi}

Alat: cangkul, terpal, mesin Chopper atau penggiling, sekop, timbangan, ember timba, terpal, plastik silo atau drum.

Bahan: Hijauan pakan berupa jerami padi sebanyak $30 \mathrm{~kg}$, tebon jagung sebanyak $30 \mathrm{~kg}$, kulit kopi $5 \mathrm{~kg}$, konsentrat berupa dedak padi sebanyak $5 \mathrm{~kg}$, starter bakteri yaitu EM4 Peternakan sebanyak 8 tutup botol, molases sebanyak $200 \mathrm{ml}$ dan air 
sebanyak 2 liter

\section{Cara kerja:}

Metode: 1. Hijauan digiling menggunakan mesin chopper untuk memperkecil ukuran dari hijauan sehingga nanti mudah diolah dan dicerna oleh ternak, 2. Setelah digiling, hijauan diletakkan diatas terpal secara merata, 3. EM4 dilarutkan kedalam air lalu di siramkan, 4. Semua bahan dicampurkan hingga homogen, 5. Masukkan kedalam plastik silo ataupun drum dan ditutup secara rapat. Proses fermentasi terjadi secara anaerob sehingga kerapatan dalam penutupan perlu diperhatikan sebab adanya kebocoran ataupun sela akan menyebabkan udara masuk dan mengakibatkan kegagalan fermentasi. Proses fermentasi berlangsung selama 7-14 hari.

\section{Pupuk organik padat (POP):}

bahan : feses kambing $30 \mathrm{~kg}$, Serbuk gergaji 5 kg, EM4 Pertanian 10 tutup botol, Molases 200 ml, dan Air 2 liter

Alat: mesin chopper, terpal, pengaduk dan plastik.

cara kerja :

Metode : 1. Pengumpulan bahan dan feses kambing yang telah kering, 2. Feses kambing digiling menggunakan mesin chopper untuk memperkecil ukuran fisik dan memperhalus tekstur kotoran kambing, 3. Feses kambing yang telah digiling selanjutnya diletakkan diatas terpal lalu diratakan dan dicampurkan dengan serbuk jergaji, 4. Larutan dekomposer terdiri dari EM4 yang dicampurkan dengan molases dan air kemudian di siramkan diatas feses yang telah bercampur dengan serbuk gergaji, 4. tingkat kelembaban pada campuran diperkirakan harus mencapai $30-40 \%$ yang diketahui dengan cara mengepalkan campuran pada tangan untuk melihat adanya kandungan air 5. Pupuk kotoran kambing dimasukkan kedalam plastik maupun drum dan ditutup rapat untuk proses fermentasi secara naerob. Proses fermentasi pupuk kotoran kambing atau bokashi berlangsung selama 7-14 hari.

\section{Tahap evaluasi dan monitoring}

Evaluasi dan monitoring merupakan kegiatan mengawasi dan pengecekan rutin terhadap pembuatan pakan fermentasi dan pupuk organik pada setiap anggota kelompok tani-ternak yang hadir dan mengikuti kegiatan praktik. Tim PHP2D memiliki agenda rutin untuk mengecek hasil dari pembuatan pakan fermentasi dari masing-masing anggota tani ternak yang mengikuti kegiatan pelatihan atau praktik. Tujuan dari kunjungan ini adalah untuk melihat hasil dari pakan fermentasi dan pupuk organik yang telah dibuat. Setiap 
selesai pelaksanaan kegiatan dilakukan evaluasi serta rapat bersama dengan tim. Selain itu juga dilaksanakan kegiatan diskusi serta survey langsung pada agenda kunjungan melalui pengisian kuisioner pada setiap kelompok tani-ternak untuk bahan evaluasi dan arsip program. Data dari hasil survei dikumpulkan dan dianalisa dengan teknik statistik deskriptif.

\section{HASIL DAN PEMBAHASAN}

Jerami padi merupakan salah satu limbah pertanian yang banyak terdapat di Desa Trebungan. Ketersedian jerami padi yang melimpah merupakan peluang bagi pemanfaatan jerami padi sebagai pakan ternak. Jerami padi untuk sebagian masyarakat sudah banyak digunakan sebagai pakan ternak ruminansia. Kebanyakan peternak memberikan jerami padi secara langsung pada ternak tanpa ada pengolahan, padahal jerami padi memiliki kandungan nutrisi yang cukup rendah sehingga membutuhkan suatu pengolahan untuk dapat dimanfaatkan secara optimal sebagai pakan ternak.

Kandungan nutrient limbah jerami padi terdiri dari karbohidrat 14,59\%, Abu 5,95\%, PK 9,93\%, LK 6,36\%, SK 9,68\%, K 0,07\%, dan P 0,65\% (Novita, et al., 2019). Salah satu teknik pengolahan untuk meningkatkan kualitas nutrisi hijauan pada bahan pakan adalah silase atau pakan hijauan fermentasi. Komposisi dari bahan pakan yang digunakan pada kegiatan ini adalah pakan komplit atau lengkap. Menurut Hartadi et al., (2008), pakan komplit merupakan pakan yang cukup mengandung nutrien untuk ternak dalam tingkat fisiologis tertentu yang dibentuk dan diberikan sebagai satu-satunya pakan yang mampu memenuhi kebutuhan hidup pokok dan produksi tanpa tambahan substansi lain kecuali air. Pemberian pakan dengan sistem pakan lengkap komplit (lengkap) akan terhindar dari seleksi pakan sehingga sebagian besar pakan akan dapat dikonsumsi dan cenderung tidak selektif saat makan (Munawaroh et al., 2015).

Pengetahuan peternak akan teknologi pengolahan pakan berupa pakan komplit terfermentasi dapat menjadi upaya alternatif untuk mengurangi intensitas merumput atau Mencari hijauan pakan ternak di berbagai tempat yang dilakukan oleh peternak. Peternak di Desa Trebungan masih mengandalkan hijaun segar dari lahan ataupun tegalan sebagai pakan ternak sehingga untuk memenuhi pakan ternak mereka harus merumput setiap hari. Hijauan akan melimpah pada saat musim penghujan namun ketersediannya akan sangat terbatas pada saat musim kemarau. Pengolahan bahan pakan tersebut menjadi pakan fermentasi atau silase.memiliki keunggulan dapat memperpanjang daya simpan pakan atau mengawetkan pakan serta meningkatkan kandungan nilai nutrsi dari hijauan utamanya 
yang berasal dari limbah pertanian. Jerami jagung dan tebon jagung sebagai hasil dari limbah pertanian tanaman pangan ketersediaanya sanga melimpah di Desa Trebungan dan hal ini menjadi suatu potensi untuk pengembangan budidaya ternak ruminansia.

Potensi pakan ternak ruminansia di Desa Trebungan adalah pertanian komiditas padi dengan lahan seluas $229 \mathrm{Ha}$ dan tanaman jagung seluas $204 \mathrm{Ha}$ (BPS Bondowoso dalam angka, 2020). Potensi tersebut berasal dari limbah pertanian yang berupa, jerami padi, dedak padi, tebon jagung, janggel jagung, dan kelobot atau kulit jagung. Menurut Supriadi et al., (2016) potensi limbah dari tanaman padi dan jagung dari 1 ha tanaman adalah 5 ton jerami padi atau tebon jagung. Kapasitas tampung ternak dari hijauan jerami padi atau tebon jagung yang tersedia dapat dihitung berdasarkan bahan kering (BK) atau bobot basah hijauan lalu di komfersikan berdasarkan Satuan ternak (ST).

Secara teoritis seekor ternak dapat mengkonsumsi bahan kering sebanyak 3\% atau bahan basah sebanyak 10\% dari bobot badannya. Satu Unit Ternak (UT) seberat $350 \mathrm{~kg}$ dapat mengkonsumsi bahan basah sebanyak $3,5 \mathrm{~kg}$ atau $10,5 \mathrm{~kg}$ BK. Berdasarkan perhitungan maka daya tampung ternak pada penanaman jagung atau padi per ha adalah 4,6 UT oleh karena itu potensi dari limbah tersebut adalah x 433 ha x 4,6 = 1.991 UT. Populasi ternak ruminansia di Desa Trebungan adalah sapi potong 638 ekor (638 UT) dan ternak ruminansia kecil yaitu kambing dan domba dengan jumlah populasi ternak masingmasing 162 ekor dan 263 ekor $(162+263=425$ ekor setara dengan 64 UT). Dihitung dari potensi limbah pertanian yang tersedia makan Desa Trebungan masih mempunyai potensi menambah populasi ternak ruminansia sebanyak 1.297 UT.
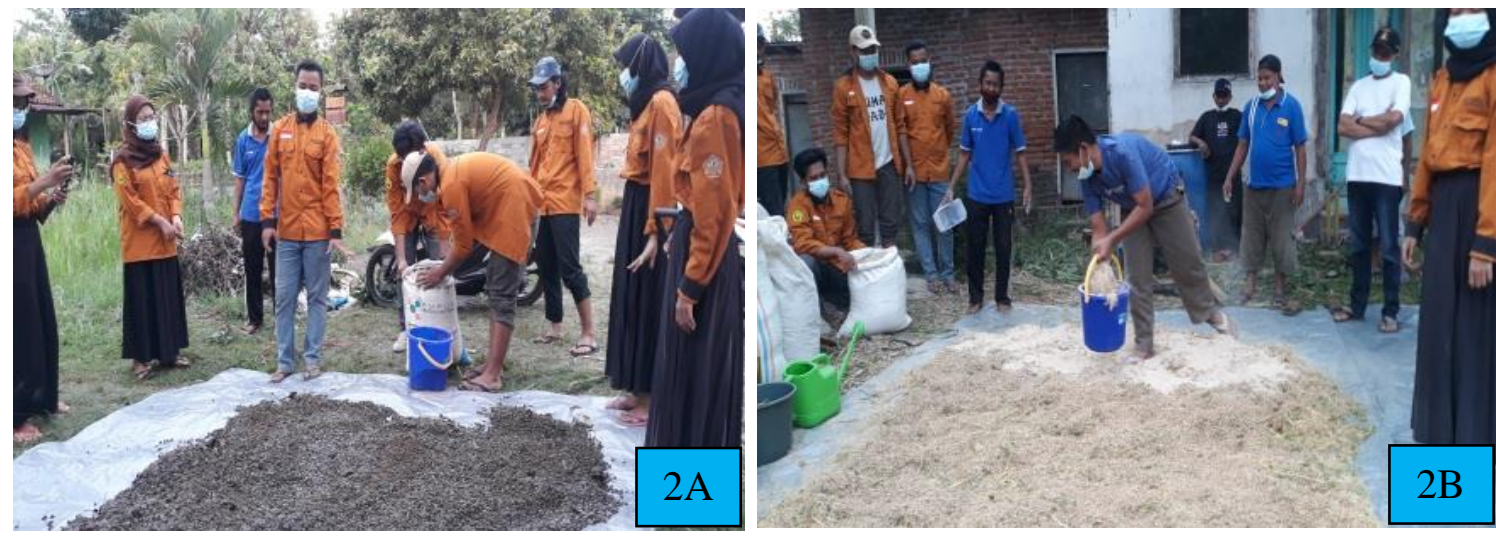

Gambar 1. Praktek pendampingan, gambar 2A. pengolahan pupuk, gambar 2B. pengolahan pakan

Potensi limbah budidaya ternak ruminansia di Desa Terbungan adalah Seekor ternak sapi dengan bobot 400-500 kg, dapat menghasilkan kotoran ternak segar (KTS) sebanyak 30-40 kg per ekor/hari. Sedangkan ternak kambing dan domba dengan bobot 30-40 kg, 
menghasilkan kotoran ternak segar sebanyak $2 \mathrm{~kg}$. Jumlah ternak sapi, kambing, dan domba yang ada di Desa Trebungan adalah berturut-turut sebanyak 638, 162, dan 263 ekor ekor sehingga dihasilkan kotoran ternak segar sebesar 19,14 - 25,520 ton KTS sapi/hari dan 0,850 ton KTS kambing dan domba/hari. Dalam satu bulan dapat memproduksi 765,60 ton kotoran sapi dan 25,50 ton kotoran kambing dan domba. Kotoran hewan ini juga memiliki potensi yang cukup besar untuk dikembangkan sebagai pupuk organik. Pupuk organik merupakan salah satu bahan yang sangat penting dalam upaya memperbaiki kesuburan tanah secara aman, dalam arti produk pertanian yang dihasilkan terbebas dari bahan - bahan kimia yang berbahaya bagi kesehatan manusia sehingga aman dikonsumsi (Musnamar, 2003).

Kotoran ternak dimanfaatkan sebagai pupuk kandang karena kandungan unsur haranya seperti nitrogen $(\mathrm{N})$, fosfor $(\mathrm{P})$, dan kalium $(\mathrm{K})$ serta unsur hara mikro diantaranya kalsium, magnesium, belerang, natrium, besi, dan tembaga yang dibutuhkan tanaman dan kesuburan tanah (Hapsari, 2013). Bahan dasar dari pembuatan pupuk organik pada kegiatan ini adalah kotoran kambing. Kotoran kambing dipilih sebab merupakan komoiti ternak utama yang banyak dipelihara oleh masyarakat setempat. Kotoran kambing sebagai limbah peternakan kebanyakan dibuang atau ditumpuk tanpa dimanfaatkan oleh masyarakat nilainya. Kotoran kambing dapat digunakan sebagai bahan organik pada pembuatan pupuk kandang karena kandungan unsur haranya relatif tinggi dimana kotoran kambing bercampur dengan air seninya (urine) yang juga mengandung unsur hara (Surya, 2013).
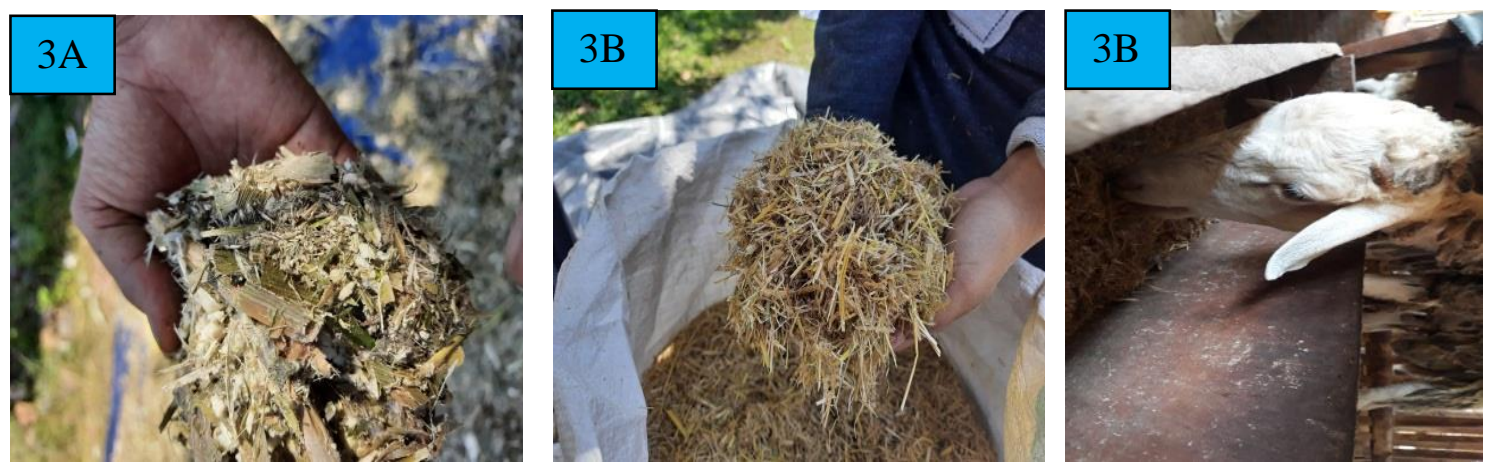

Gambar 2. Hasil pengolahan gambar 3A pembuatan pakan fermentasi, gambar 3B gambar jerami yang sudah di chopper, gambar $3 \mathrm{C}$ pemberian pakan fermentasi pada ternak.

Berdasarkan hasil Evaluasi dan monitoring terhadap peternak yang telah dilakukan oleh tim PHP2D terkait pakan fermentasi yang telah dibuat berdasarkan uji organoleptik sudah menunjukan indikator keberhasilan proses fermentasi. Pakan komplit fermentasi 
menunjukan ciri-ciri berupa aroma yang wangi khas seperti bau tape, warna kuning kecoklatan, tidak ada bau tengik dan tidak ada jamur. hal ini sesuai dengan hasil penelitian Riana et al. (2017), ciri-ciri pakan fermentasi anaerob yang menunjukan keberhasilan ditunjukan dari kualitas kimia seperti bau yang asam, warna kuning kecoklatan dan tekstur yang masih jelas seperti bahan alaminya, dan kualitas biologi yaitu adanya pertumbuhan jamur atau tidak. Penambahan aditif EM4 serta molases sebagai biostarter pada proses fermentasi pakan secara anaerob memberikan pengaruh baik terhadap kualitas fisik yaitu bau, rasa, warna dan tekstur (Herlinae et al., 2015).

Indikator adanya pertumbuhan jamur atau tidak menjadi salah satu penilaian dari kualitas biologi yang harus diperhatikan. Hasil pengamatan pada pakan fermentasi yang dibuat dapat dikatakan berlangsung dengan baik sebab tidak ada jamur. Kondisi ini menunjukan bahwa proses fermentasi secara anaerob telah berhasil dimana kerapatan dan kepadatan pakan benar-benar terjaga sehingga jamur tidak dapat tumbuh. Kebocoran pada plastik silo sebagai wadah fermentasi pakan dapat mengakibatkan pertumbuhan jamur yang mampu hidup dalam kondisi aerob. Hasil pengamatan pada masa pendampingan terlihat dari tingkat palatabilitas sapi dan domba terhadap pakan fermentasi tanpa perlu adanya adaptasi dalam waktu lama. Hal tersebut dikarenakan pakan fermentasi jerami memiliki bau yang sangat disenangi oleh ternak dan dapat secara efektif meningkatkan nafsu makan.

Prosedur pembuatan pupuk organik diawali dengan pengambilan feses kambing yang telah kering. Feses kambing diambil dari lingkungan peternak sekitar yang mana kebanyakan ditumpuk belakang pekarangan rumah. Pada kegiatan praktik, feses kambing yang digunakan adalah sebanyak $30 \mathrm{~kg}$. Feses kambing selanjutnya akan mengalami proses penggilingan menggunakan mesin penggiling. Tujuan dari penggilingan adalah memperkecil ukuran fisik dan memperhalus tekstur kotoran kambing. Kotoran kambing secara fisik memiliki tekstur yang khas yaitu butiran padat yang sukar dipecah akan mempengaruhi proses dekomposisi dan proses penyedian haranya sehingga menjadikan kotoran kambing harus digiling terlebih dahulu untuk dapat dijadikan pupuk organik. Pupuk organik ini difermentasi secara anaerob selama kurang lebih 14-21 hari dan pupuk organik yang telah matang akan dikemas dalam wadah plastik yang telah diberi label.

Hasil evaluasi dan monitoring oleh tim PHP2D kepada mitra diketahui bahwa pupuk organik yang telah dibuat secara bersama pada saat kegiatan praktik menunjukan tandatanda ke-matangan seperti aroma seperti tanah, warna hitam kecoklatan, tekstur cenderung gembur atau remah dan tidak terdapat jamur. Menurut Trivina dan Pradana (2017), pupuk 
organik yang telah matang memiliki ciri-ciri yaitu berwarna coklat tua hingga hitam, remah, memiliki suhu ruang dan tidak berbau. Pemberian EM4 pertanian sebagai bioaktivator pada proses pembuatan organik terbukti secara efektif dapat mempercepat pengomposan (Sucipto, 2012). Selain itu, penambahan serbuk gergaji pada feses kambing sebagai bahan pembuatan pupuk organik merupakan upaya memanfaatkan limbah dari sektor usaha per-kayuan yang ada di sekitar lingkungan. Serbuk gergaji diketahui dapat dimanfaatkan sebagai bahan organik pembuatan pupuk sebab memiliki tekstur yang halus dan ukuran partikel yang kecil sehingga dapat dengan mudah dikomposkan. Serbuk gergaji menngandung komponen-komponen kimia seperti selulosa, hemiselulosa, lignin dan zat eksstraktif (Sari dan Darmadi, 2016).

\section{DAMPAK}

Desa Trebungan sebelumnya sudah pernah mengadakan program sosialisasi pembuatan pakan fermentasi, namun pelatihan tersebut belum optimal karena pendampingan yang dilakukan belum sepenuhnya mencapai target dan hanya dilakukan pada beberapa anggota kelompok tani-ternak sehingga transfer ilmu belum sepenuhnya merata. Berdasarkan hasil evaluasi dan kunjungan kekandang peternak yang telah mengikuti program penyuluhan, banyak peternak yang tertarik dengan pakan komplit terfermentasi setelah dilakukan uji coba pemberian pakan pada ternak sapi dan kambing. Hal tersebut membuktikan bahwa pakan fermentasi dapat meningkatkan palatabilitas atau tingkat kesukaan ternak. Pengembangan pupuk organik dari kotoran hewan merupakan upaya meminimalisir penggunakan pupuk kimia dan limbah kotoran ternak yang sifatnya mencemari lingkungan. Pupuk organik memiliki nilai ekonomis yang tinggi sebab dapat menurunkan biaya produksi akibat pembelian pupuk kimia dan juga mempunyai potensi untuk dikomersilkan dan dapat manambah pendapatan masyarakat peternak. Tim PHP2D bersama Mitra meng-edukasi masyarakat terkait pembuatan pupuk organik yang dalam kemasan dan sudah diberikan label sehingga dapat dikomersilkan. Sambutan positif dari masyarakat terkait dengan realisasi pelaksanaan program ini menjadi motivasi untuk berlangsungnya kegiatan berikutnya sekaligus inspirasi dan inovasi pelatihan bagi kemajuan masyarakat petani-peternak khususnya didesa Trebungan, Kabupaten Bondowoso. 

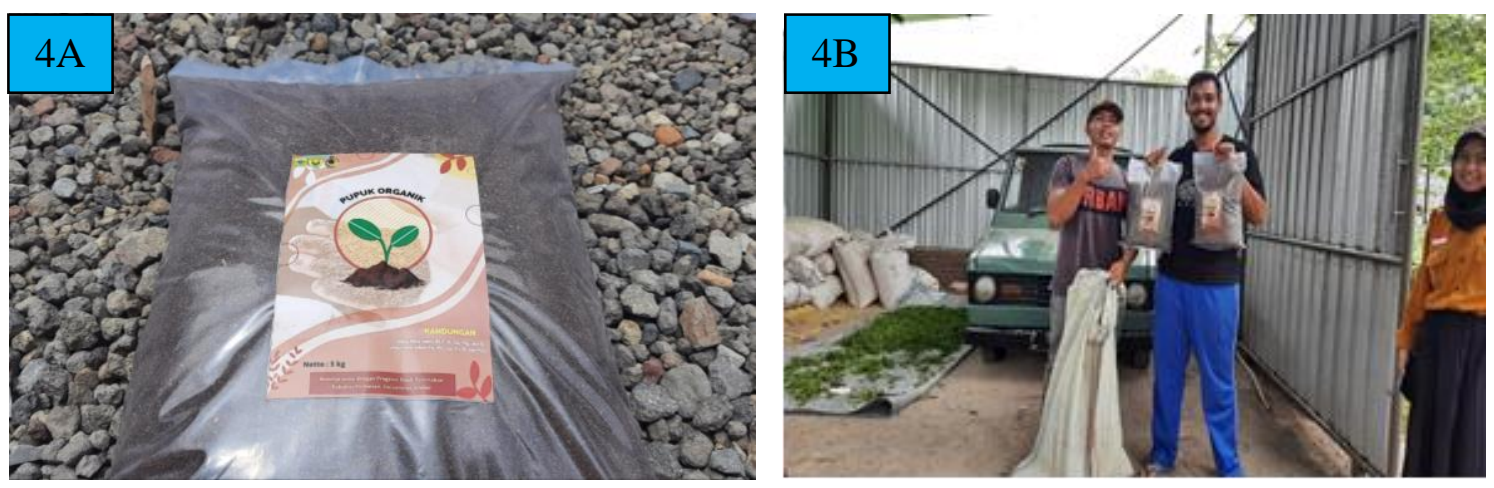

Gambar 4. Pupuk organik 4A Pupuk organik dalam kemasan dan pelabelan 4B pengemasan pupuk organik bersama mitra

\section{SIMPULAN}

Potensi limbah pertanian dan peternakan di Desa Trebungan sangat melimpah dengan total limbah pertanian diperkirakan mencapai 1.991 UT dan limbah kotoran hewan dapat mencapai total 765,60 ton kotoran sapi dan 25,50 ton kotoran kambing dan domba. Hal tersebut menjadikan penyuluhan pakan terfementasi dan pupuk organik menjadi solusi bagi pemanfaatan limbah pertanian dan peternakan yang belum diolah secara optimal. Kegiatan ini merupakan bagian dari realisasi pembangunan pertanian berkelanjutan dimana didalamnya terdapat sistem yang saling terintergrasi yaitu pengolahan limbah pertanian untuk pakan ternak dan limbah peternakan untuk pupuk pada tanaman pangan di pertanian.

\section{UCAPAN TERIMAKASIH}

Pada kesempatan ini, tim PHP2D HIMAPROSTER mengucapkan terima kasih yang sebesar-besarnya kepada semua pihak yang telah membantu sehingga pengabdian ini dapat terlaksana dengan baik, terutama kepada:

1. Kementrian Pendidikan, Pendidikan, Riset Dan Teknologi (KEMENDIKBUDRISTEK) selaku penyelenggara dan hibah dana program PHP2D.

2. Rektor Universitas Jember.

3. Dekan Fakultas Pertanian.

4. Ir. Wildan Djadmiko, M.P selaku Koordinasi Program studi Peternakan yang memberikan dukungan serta bimbingan.

5. Dr. Nur Widodo, S. Pt. M.Sc selaku Dosen Pembimbing pelaksanaan program PHP2D yang telah memberikan bimbingan penuh setiap pelaksanaan kegiatan . 
6. Dosen Program studi Peternakan yang telah memberikan masukan serta motivasi demi kelancaran kegiatan PHP2D.

7. Teman-teman pelaksana program PHP2D atas kerjasama, dedikasi dan motivasinya bagi pelaksanaan kegiatan ini.

8. Pemerintah dan masyarakat di Desa Trebungan

\section{DAFTAR PUSTAKA}

Badan Pusat Statistik. (2020). Kabupaten Bondowoso dalam angka 2021. Bondowoso: Badan Pusat Statistik.

Data Desa Trebungan. (2021). Profil Desa Trebungan Kecamatan Taman Krocok 2021. Arsip Desa Bondowoso.

Hapsari, A.Y. (2010). Kualitas dan kuantitas kandungan pupuk organik limbah serasah dengan inokulum kotoran sapi secara semianaerob .skripsi. Fakultas Keguruan dan Ilmu Pendidikan.Universitas Muhammadiyah Surakarta.

Hartadi, H., Kustantinah, R. E. Indarto, N. D. Dono, dan Zuprizal. (2008). Nutrisi Ternak Dasar. Bagian Nutrisi dan Makanan Ternak. Fakultas Peternakan Universitas Gadjah Mada. Yogyakarta.

Herlinae, H., Yemima, Y., \& Rumiasih, R. (2015). Pengaruh Aditif EM4 dan Gula Merah Terhadap Karakteristik Silase Rumput Gajah (Pennisetum purpureum). Jurnal Ilmu Hewani Tropika (Journal Of Tropical Animal Science), 4(1), 27-30.

Munawaroh, L.L., I Gede Suparta Budisatria, Bambang Suwignyo. (2015). Pengaruh Pemberian Fermentasi Complete feed Berbasis Pakan Lokal Terhadap Konsumsi, Konversi Pakan dan Feed Cost Kambing Bligon Jantan. Buletin Peternakan, 39 (3), 167-173

Musnamar, E. I. (2003). Pupuk Organik Padat: Pembuatan dan Aplikasinya. Jakarta: Penebar Swadaya.

Novita, M., D. Ramdani., H, rais., M. Zaki., U. Habibiyah., P. Z. Jati., R. Hidayat., dan R. Marta. (2019). Analisi potensi paka nuntuk pengembanagan ternak ruminansia di Kota Kampar. Jurnal Pendidikan Tambuasai. 3(3), 1701-1707

Rianah, S., Usman, Y., \& Yaman, M. A. (2017). Potensi Pakan Fermentasi Anaerob Menggunakan Bahan Pakan Lokal untuk Ternak Itik. In Prosiding Seminar Nasional Teknologi Peternakan dan Veteriner, 428-435.

Sari, E., \& Darmadi, D. (2016). Efektivitas Penambahan Serbuk Gergaji dalam Pembuatan Pupuk Kompos. Bio-Lectura: Jurnal Pendidikan Biologi, 3(6), 139-147. 
Supriadi, Lutfi, I., dan Oktriani, I. F. (2016). Potensi ketersediaan hijauan pakan limbah tanaman jagung manis di Provinsi Kepulauan Riau. Prosiding Seminar Nasional Membangun Pertanian Modern dan Inovatif Berkelanjutan dalam Rangka Mendukung MEA, 710-716.

Trivana, L., \& Pradhana, A. Y. (2017). Optimalisasi waktu pengomposan dan kualitas pupuk kandang dari kotoran kambing dan debu sabut kelapa dengan bioaktivator promi dan orgadec. Jurnal Sain Veteriner, 35(1), 136-144. 